\title{
Better Local Governance by Integrative Reorganization of State Administration and Self- Government (in Slovenia)
}

Polonca Kovač

\begin{abstract}
Rationalization and democratization of public governance and administrative organization are processes affecting all countries. The article critically evaluates the reorganization of local administration in Slovenia, aimed at increasing its effectiveness through integrative approaches at the state and local-self-government levels. Local self-government in Slovenia comprises 212 municipalities combined into 58 local state (general territorial) administrative units. Such organization is rather fragmented and weak despite several reorganization attempts since the mid-2000s. The recently planned reform for 2014-2015 tries to overcome the drawbacks typical of Slovenia, such as the two-tier public administration established in 1995 and the resulting economic local non-efficiency. The analysis of the Slovenian institutional landscape in local public administration can serve as a lesson since the strategic reorganization of political and administrative societal elements should - in addition to the search for local democracy - encompass administrative integration toward citizens, businesses and civil society to eventually achieve good local governance.
\end{abstract}

Key words: reorganization, state administration, self-government, Slovenia, good local governance

\section{Introduction}

The article critically analyzes several strategic efforts to reorganize Slovenia's local administration in order to increase the level of democracy and participation and rationalize administrative structures. Local self-government in Slovenia developed most notably in the initial period of state independence in the early 1990s. After that, rather counterproductive processes took place, resulting - despite a popula- 
tion of only 2 million - in a fragmented local authority with currently 212 municipalities and no regions, as well as a considerable degree of etatization.

Compared to the majority of Western Europe (cf. Wollmann 2011, Swianiewicz 2010), Slovenia presents a lack of systematic local rationalization. In fact, to achieve an effective and good administration, particularly regarding citizens and businesses, local authorities and public-services providers are expected to act as a harmonized system within good or collaborative governance (more in Schuppert 2011, Virant 2003). A modern local and state administration should be userfriendly and therefore meet some of the basic conditions, such as general concern for quality services, well-organized provision of information for the users, properly trained local administration staff, decentralization to ensure better responsiveness, etc. (cf. Peteri et al. 2002, SIGMA 2008, Ferfila et al. 2008, 5). Despite the need to develop strong(er) local communities, the latest Slovenian strategy on public-administration development for 2014 and onwards promotes a certain degree of unification or even centralization. External consultants suggested the reorganization of the administrative system into eight to a maximum of 12 local state-administrative districts. The reform is to be carried out simultaneously with the functional definition and territorial reorganization of state administration and the parallel (vertical) distribution of powers to/within municipalities.

The basic hypothesis of this article concerns the reorganization of local selfgovernment and/or local state administration as a reform reaching beyond the boundaries of only municipal or state structures. Since the entire public-administration system should function interdependently, any reforms should be based on prior relative qualitative and empirical analyses. Overly rapid change in the political-administrative system is contrary to empirical base and open debate, and counterproductive to the fundamental values of public administration. Moreover, it is necessary to acknowledge the rather low administrative capacity in the postsocialism environment, emphasized within local governance. The basic question of the analysis is to define elements which fundamentally distinguish local selfgovernment from (local) state administration, and to balance these with elements requiring the harmonization of both institutional settings as a unified authority. The strategic reorganization of political and administrative societal elements should encompass a systemic approach or a holistic administrative integration in order to achieve public policies' efficiency and good (local) public governance. The analysis of Slovenian institutional landscape at the local administrative level can also serve as a lesson for other small countries and Eastern European states. 


\section{Basic characteristics of Slovenian local state and self- government organization - trends and problems}

Local self-government in Slovenia represents the constitutional realization of the right of the people living in a specific area to participate in public governance decisions concerning matters of local importance (cf. the Slovenian Constitution, Articles 9, 44, 138-144, more in Ribičič 2010, Šturm et al. 2011). Since 1995, a two-tier administrative system has been in force, which gives primacy to the state government and an instrumental role to local self-government (cf. Šmidovnik 1995). The administrative process at the level of a municipality is of an executive nature in relation to national regulation but contains original self-governing elements. In order to prevent absolute concentration of political power, localize political conflicts, enable citizen participation in governance decisions and increase the quality of services, the theory of political decentralization also provides well-grounded bases for the dualism of state administration and local government. The reason for the 1995 reform of the previous municipal system with a double function of municipalities was the theoretically and traditionally separate definition of the nature and functions of these two systems. However, this approach was a political compromise, eventually leading to the current territorial fragmentation with over 200 municipalities.

Table 1: No. of municipalities in Slovenia in individual electoral terms

\begin{tabular}{|c|c|ll|}
\hline $\begin{array}{c}\text { Year of } \\
\text { estab- } \\
\text { lishment }\end{array}$ & $\begin{array}{c}\text { No. of } \\
\text { munici- } \\
\text { palities }\end{array}$ & \multicolumn{1}{|c|}{ Note } \\
\hline 1991 & 63 & $\begin{array}{l}\text { "State" communes in former Yugoslavia: unified local state } \\
\text { administration and self-government with approx. 30,000 } \\
\text { inhabitants and only up to 20\% of original local tasks }\end{array}$ \\
\hline 1994 & 147 & New municipalities: 82, 11 of which are city municipalities \\
\hline 1998 & 192 & New municipalities: 43 & \\
\hline 2002 & 193 & New municipality: 1 & \\
\hline 2006 & 210 & New municipalities: 17 & (two waves in 2006: 12+5) \\
\hline 2011 & $211-212$ & New municipalities: 2, the latest established in autumn 2014 \\
\hline
\end{tabular}

Source: own, based on official data of Government of the Republic of Slovenia.

The development of local self-government in Slovenia usually meant merely an increased number of municipalities. The latter would be established even if they often failed to meet the legal requirements, among which were a population of at least 5,000 (or 20,000 for city municipalities) and a certain infrastructure. Apparently, political maturing required - in contrast to the former state or communal municipalities - only the pursuit of the political will of the citizens to have the power "in their own hands", regardless of the lack of resources and capacity in governance. Only two municipalities, Ljubljana and Maribor, have over 100,000 inhabitants. There are approximately 50 municipalities (25\%) with 5,000 to 10,000 inhabitants, 
and a similar number of municipalities with 10,000 to 50,000 inhabitants, with an overall average of approx. 10,000. As many as 110 municipalities (52\%) do not meet the legal requirement of at least 5,000 inhabitants and some municipal administration infrastructure.

When it became obvious that a considerable part of municipalities lagged behind and failed to carry out the minimum legally prescribed basic tasks, the state tried to halt this trend by encouraging the establishment of regions and the merging of municipalities, as well as by financing joint municipal administrations. The latter was most evident in 2006 when the Financing of Municipalities Act was amended to support this type of organization by covering $50 \%$ of material expenses from the state budget. Currently, there are 49 joint municipal administrations, with 193 (90\%) participating municipalities, yet almost entirely only in the field of inspection and communal police. The total number of municipal employees (Ministry of the Interior 2014) grew from 4,277 in 2007 to 4,627 in 2012 (e.g. by 539 in Ljubljana and 0 in some other municipalities, with an average of (only) 4 new employees per municipality, which suggests that over $40 \%$ of municipalities seem to have problems finding qualified staff; cf. Ferfila 2008, 50, 72). It seems, however, that the hunger for "paper democracy" has not been satisfied yet as the above projects have not gone much beyond political consensus in public debates. The low political and administrative capacity in Slovenia is indirectly reflected in the number of mayors who simultaneously hold the office of deputies of the national parliament, with a clear conflict of interests in both theory and practice (Rakar 2013, 7). Hence Slovenia's administrative capacity is hindered by at least three elements: a legal or legislative framework that is too rigid to facilitate flexible and efficient organization, low financial and human resources and a stiff administrative culture within the municipal administrative organization (Ferfila 2008, 49, 74-85).

On the other hand, in the field of local state administration, the establishment of today's 58 state local-administrative units in Slovenia took place in 1995. A simple political transfer of jurisdiction was made, taking into account both the employees and the users, and the then number of municipalities (63; cf. Grafenauer and Brezovnik 2006, Kovač and Virant 2011, 60, Bačlija 2013, 50). While the reform was necessary, it did not bring any change in the centrality of government (cf. the role of state administration in terms of decentralization in Peteri 2002, 45, in particular the transfer of tasks in Hungary 151-160). This kind of transformation indeed led to a continuity of work (users especially had no problems), but even today it is still reflected in an unclear identity of administrative units compared to the municipalities. For the most part, administrative units are too small for an economical organization of administrative procedures and, precisely because of this, decentralization of decision-making and supervisory functions is not possible at this level (Trpin 1998, 259, Kovač and Virant 2011, 64). 
Moreover, administrative units were formed in a rather unusual way, i.e. as joint territorial branches of several ministries rather than general decentralized units of the state, such as e.g. administrative districts. Thus, even if the head of the administrative unit is appointed by the government, the administrative unit is subordinated to individual ministries. Each ministry provides to the administrative unit the relevant guidelines and instructions and exercises control over such, while at the same time conducting appeal procedures in relation to first-instance administrative acts of administrative units in individual matters (Kovač et al. 2012, 121). The 58 general administrative units mainly carry out tasks with regard to internal affairs, such as issuing documents or permitting public events, issuing building permits, deciding on rights of war veterans and victims, etc. In 2012, administrative units employed a total of 2,435 public servants (206 less than in 2011).

\section{Figure 1}

Fragmentation of over 200 municipalities and 58 state general administrative units in Slovenia

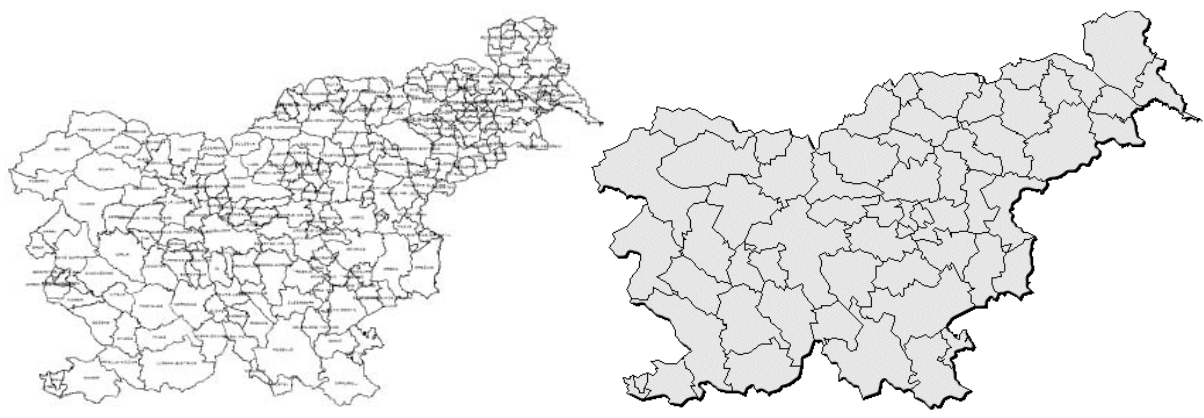

Source: Government of the Republic of Slovenia (http://www.upravneenote.gov.si/;

(http://www.arhiv.svlr.gov.si/si/delovna_podrocja/podrocje_lokalne_samouprave/obcine/).

Moreover, there are parallel territorial units of departmental state executive agencies within ministries, such as 8 police directorates, 15 tax and 10 customs offices, 12 regional surveying authorities, 6 defense offices, $8-13$ inspectorate units, etc. There are also 62 centers of work, 9,10 or 12 units of the compulsory social insurance institutes, etc., and over 200 municipal administrations. The coordination of the system is made even more difficult given the inconsistent organizational structure of public-administration bodies at the territorial level, their dispersion and lack of connection. With regionalization and related reforms, certain tasks of general local state administration (administrative units) have been or are expected to be lost in favor of municipalities (Kovač and Virant et al. 2011, 65, 94). 
A fragmented authority has both positive and negative impacts. It seems that in Slovenia, the negative ones prevail at the local level where the excessive organizational dispersion of authority generates (also) a reactive, unstable and inefficient system of political decision-making (cf. Šmidovnik 1995, Ferfila 2008). With due consideration of the necessary connection between local self-government and state administration, the new Slovenian State Administration Act (2002) introduced a mandatory integration of all local entities of power or public services into coordination councils under the authority of heads of administrative units. Amendments were adopted also in umbrella laws covering both state and municipal administrative bodies, so that the modern principles of good administration and the schemes from the citizens' charters are pursued by all local authorities. Unfortunately, in practice (see Kovač 2008) these did not achieve their full potential, neither in local reorganization according to users' needs, nor in informal co-operation.

Furthermore, constitutional disputes concerning the competences of municipalities on one hand and (general) local state units on the other were unavoidable (for more information see Ribičič 2010, 126, 220, 304, 389, Kovač and Virant 2011, 33, 79, Kovač et al. 2012, 120). The relevant decisions of the Constitutional Court of Slovenia provide several lessons concerning (a) municipality establishment, (b) division and transfer of competences between the state and local self-government, and (c) funding. The stands of the Constitutional Court of the Republic of Slovenia on these points are the following:

- In establishing a municipality (namely Ankaran, the $212^{\text {th }}$ municipality of Slovenia), it is necessary - regardless of its administrative capacity - to take into account the people's will expressed at a referendum held on the territory of the planned municipality, and not of the municipality from which the new one wishes to exit (U-I-137, 26 November 2010, and U-I-114/11, 9 June 2011); irrespective of the parliament and the principle of division of powers, the municipality was established by the Constitutional Court directly (!);

- The state's transfer of administrative tasks from the then municipalities to the new administrative units - representing the implementation of decisions in the fields whose regulation falls within the competence of municipalities (location permits, cf. Peteri 2002, 156) - means an interference with the constitutionally protected nucleus of local self-government, yet this interference is acceptable as it protects other constitutional values - legal certainty and legality (U-I-98/95, 11 July 1996);

- State interferences with the autonomy of local self-government should be evaluated similarly to interferences with human and minority rights (U-I-252/03, 18 March 2004);

- The state cannot transfer to the municipality only the execution of a decision issued by a housing inspector, as it is not possible to exclude from state competence only a single task and transfer it to the municipality. The state's compe- 
tence to carry out an inspection regarding the exercise of public interest in the field of housing, which covers several interrelated and interdependent tasks (including the administrative execution procedure), is in fact an inseparable whole (U-I-255/09, 23 June 2011).

However, funding local self-government is of key importance when deciding on the division of tasks between the state and municipalities, and two more decisions can be emphasized in this respect. First, a lower scope of the funds does not mean the incapacity of exercising local self-government, as the amount of a financial balance is always a missing difference of funds to the adequate expenditure of a municipality per capita, and its amount has no effect on exercising local self-government - yet on the other hand, two of the nine judges delivered a separate opinion stating that the regulation granting a financial balance to over two thirds of Slovenian municipalities is inconsistent with the Constitution and the European Charter of Local Self-Government (U-I-165/00, 5 December 2002). Second, given that a public utilities charge is by its nature a strictly earmarked source of financing individual municipalities, the competent body that can decide whether such will be foregone is the municipality, not the state (P-18/09, 17 September 2009).

\section{Good (local) public governance - in Slovenia and beyond}

The quality of public governance, considered as a pillar of sustainable development by OECD and the EU, largely depends on professionalism and effectiveness of public administration. Public administration is a professional apparatus with a significant influence on the quality of public policies and their implementation, and hence on the quality of citizens' life and economic competitiveness. Public-administration reforms are thus crucial for the society and the state (Kovač and Virant 2011, 30, 209, cf. Grafenauer and Brezovnik 2006). However, authorities must distinguish whether they are dealing with power - as an institution and regulator (even if only in the executive capacity), or with services for the people - as an organization and service provider. Similarly, concerning regulations, OECD (2004, cf. Statskontoret 2005) describes eight major characteristics of good governance: participatory by legitimate representatives or institutions, consensus-oriented, accountable, transparent, responsive, effective and efficient, equitable and inclusive, involving all stakeholders, following the rule of law. The old regulatory role of the state and municipality is giving way to the new role of partner (Schuppert 2000, 77, for more see 2011). Partnership lies at the heart of good governance, emphasizing efficiency, involvement and networking, as well as public/private and state/self-governing administrative structures.

Restructuring, especially in terms of regionalization, is in place all over Europe, both in countries with a long tradition of local self-government (Germany, England, France, etc.) and in the new democracies (Czech Republic, Poland, Slovakia, etc., 
more in Vlaj 2008, Swianiewicz 2010 and Rakar 2013). Constitutions are changing, new legal frameworks are being adopted, and new financial arrangements between the state and sub-state levels of authority are being developed. Consequently, local and regional communities are strengthened. Furthermore, institutional dialogue is possible between all levels and branches of governance, and citizens can participate in public matters actively. With the Council of Europe as a change driver, policy makers pursue good governance of local and regional communities to deal with public issues at a level as close as possible to the citizens (cf. the European Charter of Local Self-Government; reports and proposals of the European Committee on Local and Regional Democracy). Since the classic local governance merely refers to institutions set up to provide specific services and goods on a rather small territory, a shift from the traditional context can be observed. Modern local governance is a step forward and a much broader concept, exceeding the legal aspects and including a variety of (in)formal relations between different players in this and related fields (Bačlija 2013, 9, 98).

In this, public administration is a key factor of social development; it operates as a necessary regulator and performer of public tasks. The Slovenian legal system defines public administration as an integrated system of several segments centered around state administration, followed by the administrations of local self-governing municipalities and the holders of public authority (usually within the framework of public services delivery). According to the doctrine of good governance, public administration as an entity must establish participatory strategic planning within its own structures and in relation to other social subsystems (OECD 2004, cf. Statskontoret 2005, Kovač and Virant 2011,35). Decentralization from state to local self-government in this respect can range from a relatively small transfer of the implementing function to an almost complete transfer of all functions (the implementing, decision-making and supervisory functions), except for supervisory work, which functions as their final connecting component (Trpin 1998, 254). In this context, the transfer of jurisdiction to the local level together with the decisionmaking (and not only implementing) function could represent a positive change in Slovenia. Namely, local authorities usually show more understanding and even dedication to their local users, understand their problems better, actually solve their problems and do not merely "deliver public services", are more adaptable and creative and even more cost-effective. In sum, they implement the standards of good behavior more effectively than the central office (for Slovenia see Grafenauer and Brezovnik 2006, 150 or Ferfila 2008, 50, cf. in general Osborne and Gaebler 1994, 66-70). Thus, the concept of the autonomy of local authorities is connected especially with users' participation based on the society's democratic nature, which leads to legitimacy of administration. However, public administration can only perform this if it is directed and controlled top-down at a central level and simultaneously bottom-up by the people, i.e. the citizens. 
The concept of municipality as the basic unit of local self-government is most often correlated to the concepts of self-governance and political participation. Yet at the same time not much is said in Slovenia about the role of the municipality as a governing system or system of governance at the local level. This is one of the reasons why the implementation of political decisions in municipalities is often disregarded, poorly controlled and insufficient (cf. Ferfila 2008, 7). It is therefore positive that (local) governance develops also based on complementary models, such as transparency, participation, local decision-making, public and private networking or relations between different levels, and accountability (cf. Bačlija 2013, 97-117).

\section{Differentiation and harmonization of local self-government and state administration}

Institutional arrangements and procedures are - particularly in the initial periods of the reform movement - decisive for the progress of local governance (for more on Slovenia see Grafenauer and Brezovnik 2006, Bačlija 2013, 129). Among the key guidelines for the reorganization of local administration, one must highlight at least the setting up of the organization as a reflection of jurisdiction and functions, and not vice-versa. The type of organizational structure is determined also in the public sector by the results that an organization must achieve; an individual organizational structure is suitable for performing specific tasks under specific conditions at a specific time (Drucker 2001, 20-27). Additionally, the interconnectedness of various segments of public administration and rationalization are important. Not surprisingly, by reviewing the functional and organizational structure of public administration in their member states, the OECD and the Council of Europe $(2004,2008)$ established a parallel trend of both centralization and decentralization or deconcentration. The main trend depends on the nature of the public functions, especially in relation to users. In designing a system of local self-government and local state administration, however, other crucial differences need to be considered, as well.

First, the system of local self-government comprises a political and an administrative dimension. Only the latter - with municipal administrations representing the instrumental level of public governance in the protection of public interest and delivery of public services - is directly comparable with deconcentrated bodies of state administration. The guiding principle in the organization of local self-government is thus democracy, with public participation and co-decision-making at the local level. On the other hand, local state administration primarily strives (only) for rationalization, seeking balance between public accessibility and an organizational structure that is as cheap as possible since participation and institutional public governance as a whole are being provided by other state bodies and processes (particularly public participation in the adoption of regulations). 
Thus, in relation to local self-government, we speak of a vertical separation of powers, parallel with the various branches of power at the level of the state (legislative, executive and judiciary) or even municipality (legislative and executive, control). Local self-government in fact restricts the (ab)use of centralized (state) power, which is the foundation of a democratic system (cf. Council of Europe 2014, Sturm 2011). The overview of the number and size of municipalities varies, both within a state and between states. Contrary, the local units of state administration are usually balanced and much more comparable, since they are centrally determined and are supposed to conduct the same tasks efficiently regardless of the territorial competence.

Second, an important difference in the organization of local self-government compared to state administration refers to the objective of equality of power and services for all users within the territory of a state. The legitimate and lawful differences are present worldwide within local self-government with the quasi competition between municipalities in attracting residents and companies (cf. Osborne and Gaebler 1994, 45). In local self-government we thus speak of decentralization of power, while in the case of local units of state administration the theory emphasizes "only" its deconcentration. Namely, the state with its organizational structures functions simultaneously (a) as an authority in relation to its citizens with the monopoly of power, and (b) as a subject delivering various services - hence, as a general social organization. Both goals, democratization and efficiency, can be pursued at the same time only in state administration when delivering services (more in Kovač 2008). However, over time, the service role of the state becomes more important than its centralized authoritative role (Kovač and Virant 2011, 46). In addition, there are other factors of non-uniform status among administrative units because their size is not balanced in terms of territory size and population. Ramljak (1991, 1327-1332) emphasizes that decentralization can also represent a state or process in which extreme forms of fragmentation are not realistic. Without minimum central integration it would be impossible to perform complex tasks and impossible to ensure unity of purpose. Moreover, he emphasizes the differences between functional and geographic decentralization, in which the former refers to the relations between central and local bodies and the latter primarily to the local government in the sense of political decentralization. Decentralization would thus be possible if administrative centers with a critical mass of funds were established, albeit of a one-tier or two-tier nature.

However, to strive for better local governance at the state level, transferring the implementation of public tasks to lower hierarchical levels is also recommendable in the sense of deconcentration, which - as opposed to decentralization - is only an organizational and technical measure (cf. Ramljak 1991). Deconcentration (as highlighted by Šmidovnik 1995, 33) is merely administrative decentralization within state "authorities". The administrative units in Slovenia established in 1995 and other regional state-administration units are thus merely a result of deconcen- 
tration. A similar classification is made by Schuppert $(2011,298)$, with classic state monopoly - e.g. in security issues - on one side and welfare or public services on the other (cf. Wollmann 2011,3-7). But decentralization is also of special political importance (Peteri 2002, cf. also economic aspects by Swianiewicz 2010).

\section{Figure 2}

Basic criteria to (re)design the local administration structure

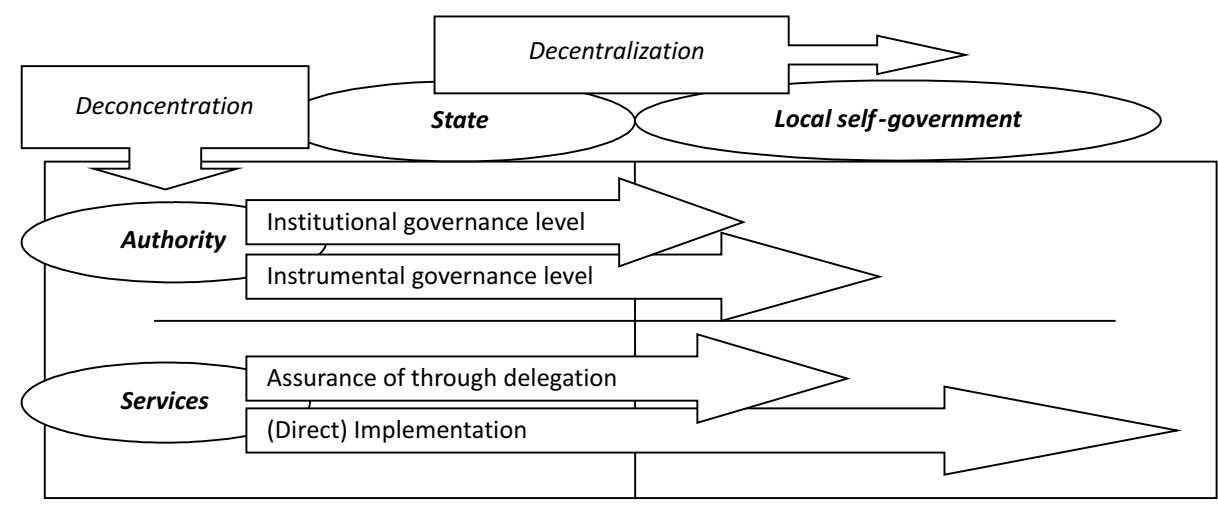

Source: own.

Nevertheless, the concept of organization is inseparably linked to notions arising in the framework of the concept of "public administration", since organization is a precondition for governance or administration. Organization is the structure in which governance processes take place, which means that contemporary problems of public administration are also problems of organization - mainly in territorial and, partly, functional terms. In the organizational sense, the role of public administration as a whole is important since rationality, efficiency and user-orientation are the reasons why the territorial principle should be pursued also in the organization of state administration, not only local self-government. As regards the integrative approach to the (re)organization at the local level, it needs to be underlined that deconcentration of public tasks is quite often an intermediate stage or a useful preparation phase for decentralization, since it is much easier to transfer tasks from local state administrative bodies to self-governing bodies rather than directly from central state administrative bodies (Grafenauer and Brezovnik 2006, 13, 150-152). It is therefore essential to distinguish when public administration acts as an institution and when it acts as an organization, while both of these aspects are related.

However, an excessive variety of organizational forms and units with a fragmented organizational structure increases the risk that the organizations will not pursue the common goal (cf. SIGMA 2008). Such an approach might impinge on the efficiency of delivering public goods as well as on the accountability that is dis- 
persed and more difficult to establish. Different numbers of local government units and of the inhabitants thereof are also characteristic of Western European countries. Altogether there are a total of approx. 90,000 local and regional administrations in the EU with 5,630 inhabitants per municipality on average. Some countries introduced one, others two or even three local self-government tiers (Council of European Municipalities and Regions 2008, cf. Vlaj 2008). Contrary to Slovenia and Eastern Europe, the West (initially, after WW2, Austria, Sweden) is characterized by (cf. general in Swianiewicz 2010, etc.)

- a shift from increasing the number of municipalities to merging municipalities, particularly in the case of low administrative capacity or duplication of administrative direction, while post-transition still prevents a mature evaluation of both goals of local governance;

- deprivatization of numerous public services, a process known as "remunicipalization" (Rekommunalisierung, Wollmann 2011, 7);

- parallel networking, i.e. state-municipal or inter-municipal co-operation as a special public-public partnership (cf. Schuppert 2011, Council of European Municipalities and Regions 2008, etc., indicating quasi-regional bodies, development forums, joint organizations and/or agreements to perform public services);

- joint organization of local self-government and local state administrations to serve the user - consequently, the common point of coordination should be located no lower than at the government or even the parliamentary level.

But it is common for all countries to constantly search for the ideal size of the municipality which should enable local democracy and identity together with economic effectiveness in the delivery of public services. Theory and comparative studies (cf. Ramljak 1991, Šmidovnik 1995, OECD 2004) indicate a positive correlation between development (of economic growth and technological progress) and decentralization, whereas others show a positive correlation between development and centralization of public administration. Hence, a modern public administration based on good governance should fulfill two goals: (a) democratization with people's participation and transparency, and (b) efficient and economical operation and use of public assets (taxpayers' money).

It can be concluded that reforms of the local organization can still be divided into two poles, namely the Western European and the Eastern European ones (cf. Wollmann 2011 and Council of European Municipalities and Regions 2008, 84). In the former, local government is reorganized based on the tradition of local democracy, while in the latter case the "new democracies" (still) reconstruct the entire local authority and public sector. Yet the common denominator of top-down rationalization of the past years is the economic and social crisis, in the West mainly with the EU troika, e.g. in Portugal, and in the East with the mergers of municipalities in 
2009 in Latvia, or the joint municipal administration in Slovenia (Rakar 2013) and the integration of state administration into general regional administrative districts (Kovač 2008). The latter further increases another development gap, namely that the population, according to evaluations and surveys carried out in Slovenia, shows no interest in participation (Bačlija 2013, 112). For this reason, in Eastern Europe one could speak not only of low capacity of the authorities, but of the society as a whole. Thus, collaborative state and governance are gaining importance also in the organization of local administration.

\section{Integrative reorganization of Slovenian local public administration in the 2014-2015 reform?}

The elements of distinction between local self-government and state administration at the local level and the importance of a coordinated system of public administration in relation to the users are summarized in the table below. The table presents the basic differences but also shows the indispensability of integrative action of public administration and the need for comprehensive reorganization, either regulatory ("hard") reorganization or ("soft") reorganization in the sense of networks between authoritative entities and common users.

In this context, when reorganizing the Slovenian local institutional landscape, the competent bodies designed several projects, primarily concerning local selfgovernment. For instance, regionalization or establishment of joint municipal administrations was introduced in 2006. However, in the past and still today there is a lack of integration mainly in terms of a redefinition of the role of the state in the society (cf. Peteri 2002, 47).

With regard to the theoretical findings and the shortcomings of the organization and organizational reforms of local self-government and/or local state administration in Slovenia in the past decades, 2013 saw the beginning of a comprehensive reorganization of local administration, with due consideration of political and administrative decentralization or deconcentration (according to the Government's Guidelines for the Establishment of Administrative Districts adopted in August 2013, cf. Governmental National Reform Program 2013). This approach - contrary to previous strategies and measures - seems promising, particularly because it is based on expert recommendations, but will bring the desired results only if political will is consistent and striving toward the development of administrative capacity at several levels. Moreover, the ministry commissioned external experts to assist with professional proposals and arguments. This expert working group strongly suggested that the harmonization of reforms be first carried out through strategies by the government, then by the parliament and among the expert public. All draft reforms should be subject to intense expert analyses of the various tasks for the transfer and status reorganization. In fact, with regard to both local self-government and state 
administration, the process of territorial (re)organization should take into account the findings of five analyses carried out before the introduction of reforms (Trpin 1998, 252): normative (with regard to the interdependence of a particular change on other parts of an administrative system), institutional, social (the impact of a reform on general social development), cost, and interest analysis (the level of actual support for specific changes among the public).

\section{Table 2}

Differentiation and harmonization of local self-government and state administration

\begin{tabular}{|c|c|c|}
\hline $\begin{array}{l}\text { Differentiation vs. } \\
\text { Harmonization }\end{array}$ & Local self-government & $\begin{array}{l}\text { (Local) State } \\
\text { Administration }\end{array}$ \\
\hline Purpose, mission & Local co-decision-making & $\begin{array}{l}\text { Ensuring implementation of } \\
\text { national public policies }\end{array}$ \\
\hline Strive for efficiency & $\begin{array}{l}\text { Democratic primarily and } \\
\text { economic }\end{array}$ & Economic primarily \\
\hline Main principles & $\begin{array}{l}\text { Participation, (local) } \\
\text { democracy, subsidiarity }\end{array}$ & $\begin{array}{l}\text { Legality, equivalence, good } \\
\text { administration: efficiency }\end{array}$ \\
\hline $\begin{array}{l}\text { Differentiation of } \\
\text { services }\end{array}$ & Yes & No \\
\hline Local division of power & Decentralization & Deconcentration \\
\hline Levels of governance & $\begin{array}{l}\text { Institutional and } \\
\text { instrumental }\end{array}$ & Implementation only \\
\hline Organization & $\begin{array}{l}212 \text { municipalities with } \\
\text { single and } 49 \text { (193 } \\
\text { participating municipalities) } \\
\text { joint municipal } \\
\text { administrations }\end{array}$ & $\begin{array}{l}58 \text { general administrative } \\
\text { units and a set of other } \\
\text { territorial departmental } \\
\text { units ( } 15 \text { tax offices, } 14 \\
\text { surveying and mapping } \\
\text { offices, } 11 \text { police } \\
\text { directorates, } 62 \text { centers of } \\
\text { social work, etc.) }\end{array}$ \\
\hline Capacity in practice & Increasing, but rather low & Rather high \\
\hline Users orientation / toward & \multicolumn{2}{|c|}{ Yes: citizens, businesses and NGOs } \\
\hline $\begin{array}{l}\text { Protection of public } \\
\text { interest }\end{array}$ & \multicolumn{2}{|c|}{ Yes } \\
\hline Civil Service System & \multicolumn{2}{|c|}{ Unified } \\
\hline $\begin{array}{l}\text { Public resources } \\
\text { (budget) }\end{array}$ & \multicolumn{2}{|c|}{$\begin{array}{c}\text { Yes, both public, } \\
\text { even municipalities in } 2 / 3 \text { out of state budget (partially) }\end{array}$} \\
\hline $\begin{array}{l}\text { Administrative and } \\
\text { judicial review }\end{array}$ & \multicolumn{2}{|c|}{ Yes } \\
\hline $\begin{array}{l}\text { Interdependence self vs. } \\
\text { state government }\end{array}$ & \multicolumn{2}{|c|}{$\begin{array}{c}\text { Yes, } \\
\text { both directions }\end{array}$} \\
\hline
\end{tabular}

Source: own.

The government required the above expert group to design a comprehensive integrative model of reorganization with an integrative approach at the level of both state administration and local self-government. This includes an integrative ap- 
proach to the (re)organization of public administration at the local level, i.e. local state administration (and in step two also municipalities). A progression of reforms is to be planned step by step in the medium term.

Initially, the existing 58 administrative units will be consolidated into 8-12. New administrative districts would deliver services and conduct administrative procedures in a centralized way only if individual tasks can be carried out independently from the number and sensibility of local users, and if procedural acts are not necessarily carried out at the micro-location (e.g. issuing acts only based on central records, amounting to about a quarter of all issues); nevertheless, some units can also specialize in specific issues (such as aliens' permits).

Then, in the following transitional year, most departmentally organized units of state administration (e.g. mapping and surveying, inspections) or other holders of public authority (e.g. social institutes in the part where social rights are being granted in administrative proceedings) will merge with administrative districts. Depending on empirical analyses and the normative specifics of tasks, some of them are to be reorganized parallel with the general units due to their specific nature of work, e.g. police directorates and branch offices of the Tax and Customs administrations (the latter merged under a special project in 2014).

Finally, municipalities will be merged, based on the primary legal criterion of at least 5,000 inhabitants, from the existing 200 to approx. 100 municipal administrations, preserving joint administrations and network partnerships with state administration. Compared to the previous stages, the main value added of this step is that centralization does not aim at rationalization (of state administration), but rather at local governance capacity-building. In fact, almost half of the existing Slovenian municipalities do not have sufficient finances and qualified staff and are thus unable to fully implement even their original tasks. The above (can) also facilitate the development of the second level of local self-government i.e. regions, following the European Charter of Local Self-Government. In the following few years, regions could take over the original tasks of local self-government that are of regional importance, and assume the role of an appeal body with respect to the decisions of municipal administrations and administrative districts instead of the presently competent yet less qualified and (in)efficient mayors and line ministries.

The new model of reorganization takes into account the necessary development of (1) democracy and (2) local governance, and at the same time strives for (3) administrative efficiency. Considering the debates so far among the expert and political public, it is interesting that, at least in principle, the first two dimensions do not seem problematic, while the third is, with warnings that administrative, and more so political, rationalization has its limits in the postulate of democracy, which should at least partly provide the local population with autonomy in public (co) governance. 


\section{Conclusion}

The world is constantly changing, and the public sector should adapt to it by proactive measures. However, when discussing local reforms, a distinction needs to be made between reforming local self-government in political terms and the administrative capacity to support (local) public governance. The reorganization of self-government and local state administration should thus be based on parallel points of departure and a simultaneous correlation between democratic and administrative efficiency. In Slovenia and in a broader Eastern European context, greater consideration is to be given to decentralization of state jurisdiction and the simultaneous merging of municipalities when the latter lack the necessary resources and capacity. There are several different approaches, either one-tier and unified administrative districts for public-service users or the introduction of two-tier regions, combining second-instance self-government and deconcentrated state administration. According to a case study of the reform of Slovenia's local governance entities planned for 2014-2015, step-by-step activities combined within a systematic reform are quite effective to achieve a harmonized local public administration. If for various (political) reasons it is not (yet) possible to establish general administrative districts by integrating all the territorial units of public administration, at least common public policies towards citizens, businesses and NGOs should be integrated in order to strive for an effective and democratic society.

\section{References}

Bačlija, Irena (ed.). 2013. Koncept in prakse lokalnega vladovanja [Concept and Practices of Local Governance]. Ljubljana: Friedrich Eber Stiftung and Faculty of Social Sciences.

Council of Europe. 2014. Available at http://www.coe.int/ (last accessed 29 July 2014).

Council of European Municipalities and Regions. 2008. Balancing Democracy, Identity and Efficiency: Changes in Local and Regional Structures in Europe. Strasbourg: Council of Europe.

Drucker, Peter F. 2001. Managerski izzivi v 21. stoletju [Management Challenges for $21^{\text {st }}$ Century; New York: Harper Business]. Ljubljana: Gospodarski vestnik.

Ferfila, Bogomil (ed.). 2008. Upravljavska sposobnost in koalicijsko povezovanje v slovenskih obcinah [Administrative Capacity and Coalition Connections in Slovenian Municipalities]. Research Report. Ljubljana: Faculty of Social Sciences.

Grafenauer, Božo and Boštjan Brezovnik. 2006. Javna uprava [Public Administration]. Maribor: Faculty of Law. 
Kovač, Polonca. 2008. "Slovenia’s Regionalisation as a Challenge for the Reorganisation of State Administration.." In Stanka Setnikar Cankar and Željko Šević (eds). Decentralisation and Regionalization: The Slovenian Experience in an International Perspective. Ljubljana: Greenwich University Press, Faculty of Administration, 157-174.

Kovač, Polonca, Iztok Rakar and Matjaž Remic (eds). 2012. Upravno-procesne dileme pri rabi ZUP 2 [Administrative-Procedural Dilemmas in the Use of the APA, 2]. Ljubljana: Official Gazette of RS.

Kovač, Polonca and Gregor Virant (eds). 2011. Razvoj slovenske javne uprave 1991-2011 [Development of Slovenian Public Administration 1991-2011]. Ljubljana: Official Gazette of RS.

Ministry of the Interior (previously Ministry of Public Administration). 2014. Available at http://www.mju.gov.si/si/zakonodaja_in_dokumenti/predlogi_ predpisov/; http://mnz.gov.si (last accessed 26 July 2014).

OECD. 2004. Principles of Corporate Governance. Paris: OECD.

Osborne, David, and Ted Gaebler. 1994. Reinventing Government: How the Entrepreneurial Spirit Is Transforming the Public Sector. New York: Addison-Wesley.

Peteri, Gyorgy, (ed.). 2002. Mastering Decentralization and Public Administration Reform in Central and Eastern Europe. Budapest: Open Society Institute.

Rakar, Iztok. 2013. "Teritorialne spremembe slovenskih občin v kontekstu EU" [Territorial Changes of Slovenian Municipalities in the EU Context]. Pravna praksa [Legal Practice] 32/1108(36), 6-7.

Ramljak, Milan. 1991. "Aktualni problemi centralizacije in decentralizacije" [Contemporary Problems of Centralization and Decentralization]. Zakonitost [Legality] 11-12, 1327-1333.

Ribičič, Ciril. 2010. Človekove pravice in ustavna demokracija [Human Rights and Constitutional Democracy]. Ljubljana: Študentska založba.

Schuppert, Gunnar Folke. 2011. "Partnerships." In Mark Bevir (ed.). The SAGE Handbook of Governance. Los Angeles: Sage, 287-299.

Schuppert, Gunnar Folke. 2000. Verwaltungswissenschaft. Verwaltung, Verwaltungsrecht, Verwaltungslehren. Baden-Baden: Nomos.

SIGMA. 2008. Drafting a Concept Paper on the Organizational Structure of the Executive Public Administration. Paris: SIGMA.

Statskontoret. 2005. Principles of Good Administration in the MS of the European Union. Available at http://www.statskontoret.se/upload/Publikationer/2005/200504.pdf (last accessed 27 July 2014). 
Swianiewicz, Pawel. 2010. Territorial Consolidation Reforms in Europe. Budapest: Local Government and Public Service Reform Initiative, Open Society Institute.

Šmidovnik, Janez. 1995. Lokalna samouprava [Local Self-government]. Ljubljana: Cankarjeva založba.

Šturm, Lovro (ed.). 2011. Komentar Ustave RS [Commentary of Slovenian Constitution]. Brdo: Faculty of State and European Studies.

Trpin, Gorazd. 1998. "Pokrajine in upravna teritorializacija" [Regions and Administrative Territory Organization]. Javna uprava [Public Administration] 2, 251-262.

Virant, Grega. 2003. "Usmerjenost k uporabniku kot načelo delovanja javne uprave" [User Orientation as a Principle of Public Administration Functioning]. Uprava [Administration] 1(2), 67-79.

Vlaj, Stane. 2008. "Regionalisation of the Republic of Slovenia." Uprava [Administration] 6(2), 7-30.

Wollmann, Hellmut. 2011. "From Public Sector-Based to Privatized Service Provision - and Reverse? Service Provision in European Countries between State, Local Government and Market." Paper presented at the IPSA RC 32 Conference, 10-12 June, in Dubrovnik, Croatia. 